\author{
Artur Mariusz Trudzik \\ https://orcid.org/0000-0002-5403-6928 \\ Instytut Polonistyki, Kulturoznawstwa i Dziennikarstwa \\ Uniwersytetu Szczecińskiego
}

\title{
Aktywność Polskiego Ruchu Wolnościowego „Niepodległość i Demokracja” (PRW „NiD”) oraz publicystyka na łamach „Trybuny” w aspekcie upamiętniania wydarzeń historycznych i pielęgnacji polskości na obczyźnie
}

\begin{abstract}
PRW „NiD” to nowoczesny kierunek polskiej myśli politycznej pokolenia wyrosłego w Polsce niepodległej, określający siebie jako Ruch, gdyż program jego nie był ujęty w sztywne i nienaruszalne formułki, lecz stanowił przedmiot stałej pracy myślowej.

(10 odpowiedzi na pytanie czym jest PRW „NiD”, w: Zasady Programowe, Londyn 1948)
\end{abstract}

\begin{abstract}
Abstrakt: Artykuł ukazuje mechanizmy oraz praktyczne działania realizowane przez Polski Ruch Wolnościowy „NiD” i jego członków, zmierzające do utrzymania polskości w warunkach uchodźczych, w szczególności związane z pielęgnacją jubileuszów (3 Maja, 15 sierpnia, 11 listopada, choć nie tylko). Istotną rolę w tym aspekcie wyznaczono organowi prasowemu - „Trybunie" oraz innym wydawnictwom związanym z Ruchem. Wypada zaznaczyć, iż tytułowa tematyka była uwypuklana głównie w latach 1945-1956, zaś później jej rola malała.
\end{abstract}

Słowa kluczowe: Polski Ruch Wolnościowy „Niepodległość i Demokracja” (PRW „NiD”), londyńska „Trybuna”, życie społeczno-polityczne Drugiej Wielkiej Emigracji.

Abstract: The article presents the main mechanisms and practical projects implemented by the Polish Freedom Movement "Independence and Democracy" (PRW NiD) (in general and members individually), aiming at maintaining Polish identity in exile. Special emphasis was put on the importance of the anniversaries (3 May, 15 August, 11 November, though not only) 
in the activity of the Movement, but also on the role played in this aspect by its press organ Trybuna, as well as other publications related to the NiD. Considering the entire history of the group, it should be noted that the theme of the title was emphasized mainly in the years 1945-1956 (this was also the first period of the Trybuna publication), and later its role was gradually decreasing. The analysis showed that the activity in the presented matter was based on three main pillars, the approximation of which was the subject of this publication.

Keywords: Polish Freedom Movement "Independence and Democracy", London monthly Tribune, social and political life of the Second Great Emigration.

Tradycja dbania o rodzimą historię, kulturę, sztukę czy pamięć zbiorową $\mathrm{w}$ formule utrwalania kluczowych z punktu widzenia historiozofii oraz ciagłości państwa wydarzeń z przeszłości w perspektywie Polskiego Ruchu Wolnościowego „Niepodległość i Demokracja” (PRW „NiD”) ${ }^{1}$ przybierała trojakiego rodzaju modus operandi: 1) organizacja i uczestnictwo w różnych ceremoniach - in gremio oraz indywidualne (zebrania, konferencje, wieczory dyskusyjne, odczyty, prelekcje i in.); 2) wydawanie dokumentów (uchwał, deklaracji, apeli itp.) w ramach ugrupowania oraz struktur, w których ono partycypowało (Koncentracja Demokratyczna, Rada Polityczna, Tymczasowa Rada Jedności Narodowej, Federacja Ruchów Demokratycznych itd.); 3) publikacje i polemika toczona za pośrednictwem „Trybuny”, czyli sui generis depozytariusza myśli społeczno-politycznej formacji (choć także w innych czasopismach pozostajaccych pod jej auspicjami). W ujęciu temporalnym analiza objęła całe dzieje

${ }^{1}$ Obecnie literatura dotyczaca ugrupowania oraz jego wydawnictw prasowych, przede wszystkim „Trybuny”, jest już dosyć obszerna, dlatego omawianie jego historii nie wydaje się konieczne. Ten stan rzeczy nie zwalnia wszakże z obowiązku choćby wskazania książek i wybranych tekstów: S. Łukasiewicz, Partia w warunkach emigracji. Dylematy Polskiego Ruchu Wolnościowego „Niepodległość i Demokracja” 1945-1994, Warszawa-Lublin 2014; A. Trudzik, Polski Ruch Wolnościowy „Niepodległość i Demokracja” $i$ jego organ prasowy - „Trybuna”. Dzieje Ruchu, periodyku i innych czasopism wydawanych przez PRW „NiD”, Warszawa 2009; idem, Myśl spoteczno-polityczna Polskiego Ruchu Wolnościowego (PRW „NiD”) $w$ latach 1945-1955, Warszawa 2010; idem, Polska i Europa Środkowo-Wschodnia $w$ perspektywie londyńskiej „Trybuny” po 1956 r., Szczecin 2016; idem, Pierwsza dekada działalności Polskiego Ruchu Wolnościowego „Niepodległość i Demokracja” (PRW „NiD”). Wspótczesna perspektywa badawcza, „Studia Medioznawcze” 2009, nr 3, s. 14-26; idem, $P R W, N i D ” i$ londyńska „Trybuna” wobec tradycji romantycznej i pozytywistycznej, w: Piekto $i$ niebo Polaków. Powstania narodowe, bunty i rewolucje. Inspiracje - kontynuacje - spory - pamięć, red. T. Sikorski, M. Śliwa, A. Wątor, t. I, Kraków 2014, s. 269-308; A. Trudzik, Portret zbiorowy członków Polskiego Ruchu Wolnościowego „Niepodlegtość i Demokracja” oraz publicystów „Trybuny”, w: Media lokalne i dziennikarstwo. Aspekty wspótczesne $i$ historyczne, red. nauk. K. Pokorna-Ignatowicz, S. Michalczyk, Kraków 2010, s. 182-205;

A. Trudzik, Paryska „Kultura”- londyńska „Trybuna”(1945-55). Idee i programy, w: Paryż - Londyn - Monachium - Nowy Jork. Powrześniowa emigracja niepodlegtościowa na mapie kultury nie tylko polskiej, red. V. Wejs-Milewska, E. Rogalewska, Białystok 2009, s. $58-81$ i n. 
PRW „NiD”, zaś wewnętrzną cezurę wyznaczały lata $1945^{2}-1955$ i 1969-1992, czyli okresy ukazywania się organu prasowego Ruchu, stanowiącego podstawę źródłową badań. Podział ten przekładał się jednocześnie na proporcje ilościowe oraz dynamike podejmowanych inicjatyw w wyodrębnionych płaszczyznach, tzn. w pierwszej dekadzie było ich zdecydowanie więcej i realizowano je bardziej intensywnie niż w późniejszych dziesięcioleciach.

$\mathrm{Na}$ wstępie wypada przypomnieć, iż ex hypothesi idea powołania do życia ugrupowania, a także koncepcyjny fundament jego funkcjonowania (uwypuklano to w „Zasadach Programowych”) były zgodne z programem Polskiego Państwa Podziemnego, zaś korzeniami sięgały do ustaleń Uniwersału połanieckiego, Manifestu Towarzystwa Demokratycznego oraz powstańczego Rządu Narodowego z 1863 r., a także późniejszych nurtów o proweniencji robotniczej i chłopskiej. Warto także dodać, że „NiD” nie należał do stronnictw historycznych - został utworzy już na emigracji, stąd jego szeregi zasilili w pierwszym rzędzie „żołnierze walczący w Armii Krajowej, w Polskich Siłach Zbrojnych na Zachodzie, członkowie podziemnych organizacji politycznych - ludzie, którzy cierpieli za Polskę w hitlerowskich obozach koncentracyjnych i sowieckich łagrach"3. Konsekutywnie - co nie było standardem we wszystkich partiach - organizacja permanentnie zabiegała o zasilanie bazy członkowskiej nade wszystko ludźmi z młodej generacji tudzież osobami z kolejnych fal uchodźczych, ale nieidentyfikujacymi lub wyraźnie odcinającymi się od współpracy z komunistami, dzięki czemu starano się, aby nie zerwano więzi pokoleniowej, a dziedzictwo przodków nie zostało zaprzepaszczone.

\section{Organizacja i partycypacja w projektach jubileuszowych}

Swoisty obowiązek prowadzenia tego typu aktywności został formalnie określony w debiutanckim wydaniu biuletynu „Nidowiec” (grudzień 1949 r.), w którym sięgając do „Zasad Programowych”, uściślono priorytetowe wytyczne (na terenie Anglii): „Podstawowym zadaniem każdej komórki organizacyjnej [...], zarówno jednostkowej jak i zbiorowej, jest dążenie do uzyskania możliwie największego wpływu na środowisko polskie, w którym się ona znajduje, dla oddziaływania na nie w duchu niepodległościowym i demokratycznym”. Służyć temu miało „wychowanie obywatelskie” ogółu ekspatriantów poprzez ich mobilizację do czynnego udziału w życiu społecznym i „wciagnięcie do pracy politycznej za pomoca powszechnych akcji o charakterze ogólnonarodowym"

\footnotetext{
${ }^{2}$ Pierwszy numer „Trybuny” ukazał się wprawdzie w 1946 r., lecz autor przyjał rok 1945 jako datę powstania periodyku ze względu na wydanie w nim dwóch jednodniówek, bezpośrednio inicjujacych zarówno drukowanie organu prasowego, jak i pozostałych czasopism. Zob. A. Trudzik, Polski Ruch Wolnościowy..., s. 180-182.

${ }^{3}$ Czym jesteśmy?, w: Zasady Programowe, Londyn 1948, s. 2-3.

${ }^{4}$ Nowy etap rozbudowy organizacyjnej, „Nidowiec” 1949, nr 1, s. 3.
} 
Wkrótce dołączono do tego katalogu trzecią niwę - informacyjno-propagandowa (tak wówczas definiowano sferę komunikowania), polegajacca na upowszechnianiu „spraw polskich wśród Brytyjczyków”. Najbardziej efektywny miał być tutaj „kontakt osobisty”, zwłaszcza że w 1950 r. tylko na terytorium Wielkiej Brytanii przebywało 150 tys. emigrantów znad Odry i Wisły, a więc gdyby każdemu z nich udało się „pozyskać dla zrozumienia historii i współczesności Polski choćby jednego Brytyjczyka”, to - jak przewidywano - rezultaty „byłyby naprawdę imponujące”.

$\mathrm{Na}$ początku lat pięćdziesiątych XX w. w związku z obchodami Święta Żołnierza Okręg Wielka Brytania „NiD” opublikował „odezwę [...] omawiająca zagadnienie odbudowy polskich sił zbrojnych na wychodźstwie oraz zasad, na jakich powinna być oparta z punktu widzenia interesu narodowego", uprzedzając strategicznie, że debata w tej materii nie powinna być sprowadzona jedynie do problemu „sztandarów i mundurów polskich”, lecz apriorycznie należało zadbać o „odpowiednie gwarancje polityczne” mocarstw zachodnich. Ulotka $\mathrm{z}$ tym apelem była rozprowadzana $\mathrm{w}$ kilkudziesięciu miejscowościach, m.in. w Londynie, Glasgow, Sheffield. W celu upamiętnienia 15 sierpnia m.in. w 1952 r. członkowie Ruchu (indywidualnie i zbiorowo) chętnie włączali się do „organizacji szeregu imprez ku uczczeniu święta”, zaś centralnej akademii w Londynie, przygotowanej przez Stowarzyszenie Polskich Kombatantów, przewodniczył nidowiec Maciej Przedrzymirski ${ }^{6}$. W 1957 r. Jerzy Studziński, sekretarz Rady Naczelnej „NiD”, pisał w liście do Rowmunda Piłsudskiego, prezesa Centralnego Komitetu Wykonawczego $(\mathrm{CKW})^{7}$, o innej, podobnej akcji: „Po uroczystej mszy św. z okazji obchodu święta trzeciego maja" rozdano w Derby 400 ulotek (tym razem dotyczących TRJN), co zaświadczało, że Ruch będąc pragmatyczny, koncentrował się na integracji spraw bieżących z uniwersalną wizją kultywowania polskości, patriotyzmu, krzewienia tradycji ${ }^{8}$.

Kampanię prelekcyjną prężnie rozwijano w Okręgu Stany Zjednoczone, zwłaszcza podczas popularnych za oceanem akademii ku czci Konstytucji 3 maja, np. w $1952 \mathrm{r}$. w Baltimore przed 50-tysięczną widownią przemawiał Jerzy Lerski ${ }^{9}$, na podobnej uroczystości przygotowanej przez Centralę Organizacji Polskich w Passaic wystapił Bolesław Łaszewski ${ }^{10}$, w Hartford - Adam

5 Trzy dziedziny pracy, „Nidowiec” 1950, nr 5, s. 3.

${ }^{6} Z$ działalności członków PRW „NiD”, „Trybuna” 1952, nr 40, s. 6.

${ }^{7}$ Więcej informacji o biografii i myśli społeczno-politycznej R. Piłsudskiego zob. m.in.: R. Juchnowski, Rowmund Pitsudski 1903-1988. Koncepcje polityczne i społeczne, Wrocław 2009; R. Piłsudski, Pisma wybrane 1972-1982, Warszawa 1998; J. Giedroyc, Autobiografia na cztery ręce, Warszawa 2006, s. 14, 34-35, 57-58, 203.

8 A. Trudzik, Polski Ruch Wolnościowy..., s. 113.

${ }_{9}$ Zob. m.in.: J. Lerski, Emisariusz „Jur”, Warszawa 1988.

${ }_{10}$ Biogram B. Łaszewskiego zob. W. Piątkowska-Stepaniak, „Nowy Dziennik” w Nowym Świecie. Pismo i jego rola ideowo-polityczna, Opole 2000, s. 450-451. 
Rudzki, natomiast w Stamford - Aleksander Mełeń ${ }^{11}$. Rok później mówcami zostali ponownie: Lerski (Chicopee), Mełeń (Filadelfia) oraz Włodzimierz Marian Drzewieniecki ${ }^{12}$ (Milwaukee) ${ }^{13}$, a w 1954 r. Łaszewski był głównym referentem w trakcie „Dnia Polskiego” (Mahony) ${ }^{14}$.

Jednocześnie wraz z obchodami państwowymi, narodowymi w środowisku „NiD” na równych prawach celebrowano święta (Boże Narodzenie, Wielkanoc etc.) i uroczystości religijne przybierające postać m.in. „wieczorów opłatkowych". Jako przykład można podać przebieg takiego spotkania z $1953 \mathrm{r}$. w Kole Chicago. Zostało ono podzielone na dwie części: „poważną w czasie której odśpiewano kolędy” i wygłoszono „okolicznościowe przemówienia” (m.in. Władysław Jaroszewski ${ }^{15}$, Drzewieniecki) oraz ,artystyczna [Marek Gordon ${ }^{16}$, Zbigniew Tadeusz Chałko ${ }^{17}$ - A.T.] wraz z zabawa”. Mimo że „opłatek urzadzony był $\mathrm{w}$ ramach ściśle wewnętrznych, zgromadził nie tylko liczne grono członków" ugrupowania z rodzinami, ale też jego sympatyków, a ponadto „gości z Chicago i dalekiego Wisconsin”. Pomyślny przebieg imprezy i nieskrywane zadowolenie uczestników dowodziły „szczerych więzów koleżeńskich łączących nidowców na terenie środkowego zachodu”, a wyśmienita aura i „prawdziwie polska atmosfera” w dużej mierze były zasługa ,sympatycznych pań-organizatorek"18 (w tym Barbary Chałko) ${ }^{19}$. Wydawnictwa Ruchu niejednokrotnie przekazywały do powszechnego obiegu materiały otrzymywane od „zaprzyjaźnionych” stowarzyszeń czy instytucji. Jerzy Skoryn-Lipski²0, delegat CKW i Koła Armii Krajowej w Meksyku, przesłał „Komunikat Informacyjny Delegatury Koła AK na Meksyk”, powiadamiajacy, że 30 VII 1955 r. w stolicy tego kraju odbyła się „uroczystość wręczenia kopii cudownego obrazu Matki Boskiej Częstochowskiej”, zyskując szeroki rezonans w lokalnych mediach i owocujac wieloma „przychylnymi Polsce artykułami i słuchowiskami radiowymi" 21 . Podobnych inicjatyw zaplanowanych przez Ruch było oczywiście więcej, np. akademia ku czci 300-lecia obrony Częstochowy (przygotowana w tym samym roku $)^{22}$.

${ }^{11} Z$ działalności PRW „NiD”, „Trybuna” 1952, nr 38, s. 8.

${ }_{12}$ Biogram W.M. Drzewienieckiego zob. A. Trudzik, Polska i Europa Środkowo-Wschodnia..., s. 302.

${ }_{13}$ Przemówienie trzeciomajowe, w: Kronika organizacyjna, „Trybuna” 1953, nr 46, s. 8.

${ }_{14}$ Sprawy organizacyjne, informacje i komunikaty, „Komunikat Informacyjny” 1953, nr 6, s. 12.

${ }_{15}$ Biogram W. Jaroszewskiego zob. A. Trudzik, Polska i Europa Środkowo-Wschodnia..., s. 310.

${ }^{16}$ Biogram M. Gordona zob. ibidem, s. 306.

17 Biogram Z.T. Chałki zob. ibidem, s. 298.

${ }_{18}$ Uczestnik, Opłatek Koła Chicago, w: Kronika organizacyjna Ruchu, „Biuletyn Informacyjny" 1954, nr 10, s. 5.

19 Biogram B. Chałko zob. A. Trudzik, Polska i Europa Środkowo-Wschodnia..., s. 298.

${ }^{20}$ A. Trudzik, W cieniu „zimnej wojny”. Europa Zachodnia $i$ świat $w$ optyce londyńskiej „Trybuny” po 1956 r. (w opracowaniu).

${ }_{21}$ Meksyk, w: Okno na świat, „Biuletyn Informacyjny” 1955, nr 22, s. 10.

${ }^{22}$ A. Trudzik, Polski Ruch Wolnościowy..., s. 80-82. 
Od lat sześćdziesiątych wcześniejszy impet w partycypacji oraz organizowaniu jubileuszów systematycznie spowalniał, szczególnie z powodu zmodyfikowania po 1956 r. fundamentalnej doktryny Ruchu z zasady: „Kraj - przetrwanie, emigracja - walka o niepodległość” w kierunku „służebnej roli uchodźstwa wobec Kraju"23, dlatego np. w 1980 r. odwołano się do opozycji w Polsce i zacytowano w „Trybunie” komunikat gdańskiej Konfederacji Polski Niepodległej „w sprawie pobicia przez SB organizatorów obchodu” święta 3 Maja, co egzemplifikowało różnice w podejściu władz do praw człowieka i obywatela, a tym samym możliwości pielęgnowania rocznic przez rodaków uciemiężonych w komunistycznej Polsce i mieszkających na demokratycznym Zachodzie ${ }^{24}$.

Otwartość periodyku, przejawiająca się w udostępnianiu łamów nie tylko członkom „NiD”, po raz kolejny potwierdziła się w 1982 r., kiedy zamieszczono tekst Jerzego Gawendy ${ }^{25}$, informujący o wygłoszonym przez niego w stolicy Wielkiej Brytanii przemówieniu pierwszomajowym, będącym w tym roku wyjątkowym dla socjalistów na obczyźnie, ponieważ po długoletnim rozbiciu tego obozu (od momentu waśni liderów: Adama Pragiera, Zygmunta Zaremby, Adama Ciołkosza) ${ }^{26}$ udało się powołać Komisję Połączeniowa Socjalistów Polskich na Emigracji (Centralny Komitet Polskiej Partii Socjalistycznej [PPS], Centralny Komitet Zagraniczny PPS, Związek Zagraniczny Socjalistów Polskich), mająca przygotować podwaliny pod „zjazd połączeniowy w 90-ta rocznicę powstania PPS". W artykule opracowanym dla kwartalnika znalazły się odniesienia do zależności: Kraj-wychodźstwo, w tym passus uzasadniający, że 3 maja był i pozostaje „symbolem odrodzenia się narodu poprzez epokowa i rewolucyjna, jak na owe czasy Konstytucję" oraz pośrednio porozumienia sierpniowe rozumiane jako „wymuszonym na reżymie przez zryw stoczniowców, nowym odrodzeniu narodu, tym razem symbolizowanym przez święto robotnicze 1 maja"27.

Największa wada powojennej emigracji, czyli wręcz chroniczna niemoc w zawarciu konsensusu politycznego, towarzyszyła niestety również wspólnemu świętowaniu jubileuszów narodowych. Tym bardziej warto przytoczyć, wprawdzie rzadki, ale jednak przypadek kompromisu między skonfliktowanymi na co dzień partiami. Jedność ta de facto została poniekąd wymuszona czynnikami zewnętrznymi ${ }^{28}$. Chodzi tu o okoliczności zbudowania i odsłonięcia w Londynie w 1976 r. pomnika-hołdu zamordowanym w Katyniu, będącego

${ }^{23}$ Idem, PRW „NiD” $i$ londyńska „Trybuna”..., s. 291.

${ }^{24}$ Trzeci maj $w$ Gdańsku, „Trybuna” 1980, nr 35/91, s. 31.

${ }_{25}$ Biogram J. Gawendy zob. A. Trudzik, Polska i Europa Środkowo-Wschodnia..., s. 304.

${ }^{26}$ Warto tu zwrócić uwagę m.in. na prace: A. Siwik, Polska Partia Socjalistyczna na emigracji w latach 1945-1956, Kraków 1998, s. 260; idem, Polskie uchodźstwo polityczne. Socjaliści na emigracji w latach 1956-1990, Kraków 2002.

27 J. Gawenda, Refleksje pierwszomajowe, „Trybuna” 1982, nr 41/97, s. 22-23.

${ }^{28}$ Jak należy dziś działać, w: Wydarzenia i komentarze, „Trybuna” 1976, nr 24/80, s. 26. 
„wielka manifestacją na rzecz sprawy wolności Polski”. Zapewne przebieg wydarzenia zostałby pominięty przez brytyjską opinię publiczną (jak gros tego typu przedsięwzięć), jednak stało się inaczej ze względu na... dziesięć protestów władz reżymowych z Polski i ZSRR, domagajacych się od Brytyjczyków zakazu wzniesienia monumentu, oraz dodatkowe kłopoty, jakie w efekcie tych żądań dotknęły komitet budowy postumentu, tzn. trudności w ,znalezieniu dla niego miejsca, następnie bojkotu ze strony brytyjskich czynników oficjalnych samej uroczystości”, wreszcie zakazanie żołnierzom w służbie czynnej występowania podczas obchodów w umundurowaniu etc. Decyzje te okazały się nieskuteczne, albowiem Brytyjczycy poczuli się dotknięci „uległością rządu laburzystowskiego, wobec nacisków sowieckich i cała sprawa nabrała znacznego i korzystnego z punktu widzenia interesów polskich rozgłosu w prasie, radiu i telewizji" ${ }^{29}$. Niestety, nawet po 40 latach, które minęły od tego czasu, w sytuacji gdy Polska znajduje się w NATO, Unii Europejskiej, horrendalnym paradoksem jawi się to, że miejsca upamiętnienia ludobójstwa dokonanego w Katyniu i jego okolicach moga być w wolnym świecie, a tym bardziej Stanach Zjednoczonych, traktowane analogicznie jak w dobie zimnej wojny przez komunistów... ${ }^{30}$

\section{Wydawanie dokumentów i akcja quasi-dyplomatyczna}

Ta dziedzina funkcjonowania Ruchu w szerokim planie odgrywała dużą rolę ${ }^{31}$, aczkolwiek w kontekście pielęgnacji rocznic, stanowiących motyw przewodni tego numeru „Dziejów Najnowszych”, trzeba uznać, że były to raczej działania pojedyncze, akcydentalne.

Podpisana 30 VI 1947 r. Deklaracja Koncentracji Demokratycznej (KD) (PRW „NiD”, PPS, Stronnictwo Pracy, Porozumienie Stronnictw Demokratycznych) w punkcie 4 stanowiła, że KD będzie „uważać za swój najwyższy

${ }_{29}$ Wnioski z obchodu katyńskiego, w: Wydarzenia i komentarze, „Trybuna” 1976, nr 24/80, s. 26.

${ }_{30}$ Walter Gołębiowski w imieniu m.in. Światowej Rady Badań nad Polonia, Kongresu Polonii Amerykańskiej na Florydzie zwracał się do burmistrza Jersey City Stevena Fulopa: „Piszę ten list w imieniu społeczności polonijnej na świecie oraz naszych rodaków w Polsce, aby wyrazić nasze zaniepokojenie nagłym zawiadomieniem o planach przeniesienia pomnika Pamięci Katynia z Exchange Place w Jersey City. Dla Amerykanów polskiego pochodzenia, oraz naszych Rodaków w Kraju Pomnik Katyński jest symbolem polskiego bohaterstwa i tragedii Polskiego Narodu podczas II wojny światowej, kiedy to Polska była okupowana przez Niemcy i Związek Radziecki. Pomnik Katyński został odsłonięty w 1990 roku po długim wysiłku społeczności polonijnej i amerykańskiej, która obejmuje wielu amerykańskich i polskich weteranów wojennych, aby przypomnieć o kosztach wolności”. List Prezesa ŚRBnP do burmistrza New Yersey w sprawie pomnika katyńskiego 4 V 2018 r., http:// srbnp.pl/index.php/bez-ktegorii/88-list-prezesa-srbnp-do-burmistrza-new-yersey-w-sprawie-pomnika-katynskiego (dostęp: 15 XII 2018).

31 Zob. m.in.: A. Trudzik, Polski Ruch Wolnościowy..., s. 473-526. 
nakaz istotną wolę kraju i będzie - wedle swego najlepszego rozumienia - reprezentować tę wolę, przeciwstawiając się wszelkiemu totalitaryzmowi w obronie wolności i własnej kultury narodu polskiego" ${ }^{2}$. Z kolei zalecenia Ruchu dla wychodźstwa en bloc sprowadzały się w tym samym okresie do pięciu dezyderatów implikowanych zarówno z „Zasad Programowych”, jak i ówczesnych determinantów geopolitycznych: 1) „oddziaływanie na ośrodki dyspozycji politycznej wolnego świata [przez] kierownictwo polityczne Emigracji; 2) urabianie opinii publicznej społeczeństw zachodnich przez masową akcje informacyjna, w której udział powinien brać każdy wolny Polak; 3) chronienie wartości kultury narodowej, którym grozi zniszczenie w Kraju; 4) rozwijanie niezależnej myśli politycznej” na uchodźstwie; 5) „szkolenie kadr” dla odbudowy przyszłej, niepodległej Polski ${ }^{33}$.

Dwie dekady później „NiD” partycypował w drugim - używając dzisiejszego języka - ponadpartyjnym czy międzypartyjnym ciele politycznym, tj. Federacji Ruchów Demokratycznych, której Rada przyjęła 16 XI 1968 r. uchwałę uwydatniającą wymowę i doniosłość rocznicy 50-lecia odzyskania przez Polskę niepodległości. Dokument zawierał m.in. znamienny akapit: „Naród polski, który w czasie rozbiorów oparł się wynarodawianiu, powstrzymał w roku 1920 najazd za wschodu grożący zalewem nie tylko Polsce, ale i całej Europie, przetrwał okupację hitlerowską zmierzająca do zupełnej jego zagłady, powrócił na stare ziemie piastowskie oraz nie poddał się obcej mu ideologii komunistycznej - wykazał żywotność stanowiąca gwarancję trwałości państwa polskiego" ${ }^{34}$. Nie bez znaczenia było wyeksponowanie, że po II wojnie światowej uczynienie z Polski „satelity Moskwy” stanowiło nie tylko następstwo imperializmu sowieckiego, ale i efekt jej „opuszczenia przez Zachód”, dlatego dopóki społeczeństwo nad Odrą i Wisłą będzie terroryzowane przez reżym, nie uzyska wolności słowa, zrzeszania się itp., dotąd na obczyźnie konieczna będzie egzystencja sił politycznych „pomagających krajowi w jego dążeniu do odzyskania wolności”. À propos w tekście odniesiono się również do inwazji wojsk Układu Warszawskiego na Czechosłowację w 1968 r., uwypuklając tym samym zbieżność interesów wszystkich narodów bloku wschodniego ${ }^{35}$.

W nieco odmiennej konwencji 13 XII 1970 r. uczestnicy Zjazdu PRW „NiD” wystosowali apel do emigracyjnej młodzieży, będący sui generis programem określającym sposoby zachowania tkanki narodowej na obczyźnie w drugiej połowie XX w. Otóż pielęgnowanie i kultywowanie tradycji, szacunek dla przeszłości pozostawały niezmiennie imperatywem, lecz $\mathrm{w}$ pewnym momencie, w konsekwencji m.in. przeobrażeń cywilizacyjnych, konieczne było przewartościowanie „dogmatów i doktryn polityczno-gospodarczych”, przede

\footnotetext{
${ }^{32}$ Deklaracja Koncentracji Demokratycznej, „Trybuna” 1947, nr 11, s. 9.

${ }_{33}$ Jak walczyć o niepodlegtość, „Trybuna” 1951, nr 34, s. 11.

${ }^{34}$ W rocznice 50-lecia, w: Dokumenty, „Trybuna” 1969, nr 1, s. 25.

${ }^{35}$ Ibidem.
} 
wszystkim ze względu na „powszechny i głęboki ferment w środowiskach intelektualnych” oraz wśród studentów, wynikający z „niepewności jutra” ${ }^{36}$.

Mimo zmieniających się realiów formacja nie zaniechała jednak aktywizowania politycznego wojennej i powojennej emigracji oraz Polonii wcześniej zakorzenionej na Zachodzie, podając jako wzór do naśladowania sprawny i pragmatyczny Komitet Wyborczy Polaków Naturalizowanych we Francji (Comité Électoral des Polonais Naturalisés), na którego czele przez wiele lat stał członek władz „NiD” - Jerzy Jankowski ${ }^{37}$. Jedną z metod działania Komitetu było pozyskiwanie dla sprawy polskiej francuskich decydentów według określonej procedury: „nakłonienie rodaków do udziału w wyborach”, wyjaśnienie im, dlaczego warto oddać głos na konkretnego kandydata, zachęcenie ich do udzielenia poparcia $\mathrm{w}$ zamian za zobowiązanie się polityka do rozwiązania konkretnego problemu tamtejszej Polonii. W ten sposób udało się np. wyperswadować „wydanie znaczka pocztowego dla uczczenia 50. rocznicy masowego przybycia Polaków do Francji”, będącego „hołdem złożonym przez rząd francuski swoim obywatelom języka polskiego za wkład jaki wnieśli w bogacenie i obronę Francji”, oraz poczyniono zabiegi na rzecz „zdawania na maturze (baccalaureat) języka polskiego, jako języka nowożytnego" ${ }^{38}$.

\section{„Trybuna” - panoptikum przełomowych wydarzeń w dziejach Polski}

Rozpoczynając tę część, trzeba zaznaczyć, że po pierwsze, w pluralistycznej „Trybunie” z nieskrywaną estymą sięgano do chlubnych, sławetnych dat $\mathrm{z}$ historii Polski, ale równocześnie nie unikano zagadnień trudnych, kontrowersyjnych lub po prostu złych doświadczeń z przeszłości, które winny być przestrogą dla rodaków żyjących $\mathrm{w}$ XX w. ${ }^{39}$ Po wtóre, wiodąca dla tego korygowanego artykułu była problematyka rocznic upamiętniających chwalebne czyny z przeszłości, ale uwzględniając, że Ruch istniał na politycznej mapie wychodźstwa niemal pół wieku, chyba uzasadnienie miało ustalenie, jakie precedensy po 1939 r. przykuwały uwagę publicystów, redaktorów, uznających je za „symbole nowych czasów”. Po trzecie, redakcja stosowała dwa sposoby przedstawiania zagadnienia pielęgnacji polskości na obczyźnie, tzn. publikowała teksty opracowane metodą stricte historyczną oraz paralelna ze współczesnością.

$\mathrm{W}$ artykule otwierajacym numer 39 pisma z $1952 \mathrm{r}$. pojawiło się swoiste uwierzytelnienie przyjęcia takiej systematyki: „W życiu każdego narodu sa

\footnotetext{
${ }^{36}$ J. Studziński, Próba koordynacji, w: Listy do Redakcji, „Trybuna” 1970, nr 6/62, s. 17.

${ }_{37}$ Biogram J. Jankowskiego zob. A. Trudzik, Polska i Europa Środkowo-Wschodnia..., s. 310.

38 J.[erzy] Jankowski, We Francji uczymy sie gryźć, „Trybuna” 1973, nr 14/70, s. 12-14;

A. Trudzik, Polska i Europa Środkowo-Wschodnia..., s. 25-26.

${ }^{39}$ A. Trudzik, Polski Ruch Wolnościowy..., s. 383, 406.
} 
daty - symbole o głębokiej treści politycznej. My, Polacy, lubujemy się w akademiach i obchodach minionych wydarzeń. Czcimy z równym namaszczeniem dni zwycięstwa i dni klęski, składając przede wszystkim hołd bohaterstwu i krwi przelanej dla sprawy narodowej, a mniej się wgłębiamy w przyczyny, które zdecydowały o wyniku każdorazowych zmagań" 40 .

Zgłaszana konieczność myślenia dedukcyjnego, wyciagania wniosków z przeszłości, ale i ewolucja programowa formacji odnośnie do postrzegania symboli historycznych w stosunku do aktualnego położenia Kraju i uchodźstwa były nader widoczne w latach siedemdziesiątych XX w. Krytyka ugrupowania, wyrażana głównie za pośrednictwem organu prasowego, ogniskowała się w niemałym stopniu wokół ośrodka „zamkowego” lubującego się w „talmudycznych dyskusjach", np. dotyczących Konstytucji kwietniowej, która była natenczas „takim samym zabytkiem muzealnym, jak Konstytucja 3-go Maja, z tą tylko różnica, że w historii Polski nie miała ona równie dobrego imienia" ${ }^{41}$. Jednocześnie w „Trybunie” eksplikowano, że wbrew wypowiadanym bezpodstawnie zarzutom „NiD” nie lekceważył „znaczenia emocjonalnego, a także politycznego niektórych symboli”, przy czym stał na stanowisku, iż „symbol symbolowi był nierówny", a więc zestawianie konstytucji z maja $1791 \mathrm{r}$. i kwietnia 1935 r. niczym nie różniło się od porównywania „pieczęci Rządu Narodowego 1863 r. i pieczęci «rządu» z Eaton Place”, a faktycznie „analogia pomiędzy tymi dwoma pieczęciami, była taka sama, jak między Trauguttem, a "premierem» zamkowym, między bohaterstwem i męczeństwem, a bezpiecznym i wygodnym dożywaniem starości nad Tamiza" 42 - konkludowano.

W londyńskim periodyku niezmiennie recypowano 15 sierpnia jako uosobienie tryumfu w 1920 r., ale zdarzało się, że symultanicznie przywoływano wrzesień, czyli synonim klęski z 1939 r. Esencja tekstu o takiej proweniencji, opublikowanego w 1972 r., stanowiła automatycznie aluzję do ówczesnej rzeczywistości politycznej na wychodźstwie: wiktoria z 1920 r. nie byłaby „możliwa, gdyby Polską nie kierował [...] rząd jedności narodowej”, natomiast pozycja Kraju w 1939 r. „byłaby też znacznie silniejsza, gdyby ówczesny polski system polityczny był wykładnikiem wszystkich żywotnych sił narodu, a zwłaszcza klasy chłopskiej i robotniczej" ${ }^{43}$. Bitwa Warszawska powróciła na łamy tytułu jeszcze raz w $1980 \mathrm{r}^{44}$, a niejako przy tej okazji - Piotr Wandycz ${ }^{45}$, historyk i ceniony znawca dziejów Europy Środkowo-Wschodniej,

\footnotetext{
${ }^{40}$ Nauka z przeszłości, „Trybuna” 1952, nr 39, s. 1.

${ }^{41}$ S.P., Śmieszne i smutne, w: Wydarzenia i komentarze, „Trybuna” 1970, nr 6/62, s. 29-30.

${ }^{42}$ Symboliści, w: Wydarzenia i komentarze, „Trybuna” 1972, nr 12/68, s. 31; A. Trudzik, Polski Ruch Wolnościowy..., s. 122-123.

${ }_{43}$ Symboliści..., s. 31.

${ }^{44}$ Historyczne znaczenie bitwy warszawskiej, „Trybuna” 1980, nr 35/91, s. 29.

${ }^{45}$ Tekst wspomnieniowy o P. Wandyczu zob. S. Łukasiewicz, Sp. Piotr Wandycz z perspektywy Lublina - pożegnanie, „Yearbook of the Institute of East-Central Europe” 2017, t. XV, nr 1, s. 253-257.
} 
ewokował i komentował sens militarno-polityczny „wyprawy kijowskiej” i w jej konsekwencji „pokoju ryskiego, który nie tylko nie załatwiał żadnej istotnej sprawy między Polska a Rosją [...], a był, bo musiał być zarzewiem dalszych konfliktów”, a dodatkowo „załamania się [...] «federalistycznej» polsko-litewsko-białorusko-ukraińskiej" 46 .

W kategorii traumatycznych doznań z przeszłości, w jednodniówce poprzedzającej ukazanie się inauguracyjnego wydania „Trybuny”, w rozbudowanym materiale ustosunkowano się do konfederacji targowickiej, poprzedzajac go wstępem redakcyjnym, w którym podnoszono prawidłowość, że historia magistra vitae est, ale automatycznie przestrzegano, że „sytuacje w historii narodów często bywają analogiczne, ale nigdy nie są identyczne”. Poza tym napominano, że nie można subiektywnie generować jakichś faktów, modyfikować ich znaczenie, aby na tej podstawie „usprawiedliwiać bieżace koncepcje i posunięcia polityczne, zrodzone w gruncie rzeczy bez żadnego udziału prawdziwej myśli politycznej”. Takie postępowanie ugrupowanie piętnowało już od 1946 r., kiedy część uchodźstwa „drapowała się na wielopolszczyznę”, a w praktyce podejmowane przez nią decyzje „były bliższe Targowiczanom niż Wielopolskiemu”, wobec czego mniemana „"wielopolszcyzna» wyglądała raczej jak "wielorosyjszczyzna»". Autor artykułu charakteryzował ponadto targowiczan: inicjatora konfederacji Seweryna Rzewuskiego, zaznaczajac, że początkowo był on wrogo nastawiony do Rosji; Stanisława Szczęsnego Potockiego - „o dość ograniczonej inteligencji i nie posiadającego dotychczas żadnej przeszłości politycznej”; Ksawerego Branickiego - „hetmana wielkiego koronnego"; Szymona Kossakowskiego - „generała majora w wojsku litewskim", po czym opisał ciekawie przebieg przygotowań do haniebnego czynu oraz toczonych walk ${ }^{47}$.

Publikację tę rozpoczynała nomen omen pointa:

Konfederacja targowicka nie była wyłącznym dziełem zdrajców - z rzemiosła. Ludzie tego pokroju żyjący na żołdzie „wspaniałomyślnej” imperatorowej rosyjskiej, jak Kossakowscy, lub wypasienie na jej protekcji, jak Ksawery Branicki, stanowili najliczniejszy zastęp [...] i z czasem zdobyli największe wpływy. Właściwi jednak twórcy konfederacji byli ludźmi, których do zgubnego związku z Rosją popchnęło polityczne zacietrzewienie oraz zadraśnięte ambicje osobiste, którym zaślepienie oraz naiwność polityczna, przesłoniły oczy na rzeczywisty obraz Polski i jej międzynarodowe położenie ${ }^{48}$.

Termin „targowiczanie” zagościł w „Trybunie” jeszcze raz w latach siedemdziesiątych, lecz użyto go publicystycznie, jako przenośni wobec środowiska „Jutra Polski” i Stronnictwa Ludowego, które wysuwało jawnie postulat

\footnotetext{
${ }^{46}$ P. Wandycz, Wyprawa kijowska, „Trybuna” 1980, nr 36/92, s. 20-24.

${ }^{47}$ Redakcja, ***, „Pół drogi do wolności” (jednodniówka PRW „NiD”), VI 1945, s. 8.

48 Scriptor, Konfederacja targowicka. Montaż mechanizmu zdrady, „Pół drogi do wolności” (jednodniówka PRW „NiD”), VI 1945, s. 8.
} 
„bezzwłocznego - im prędzej tym lepiej - zmienienia naczelnych władz, reprezentujących Polskę”, mimo że wcześniej „zatwierdziło [ono] uchwały jałtańskie, odnośnie przyznania prawie połowy Polski dla Rosji oraz zgodziło się na narzucenie jej rządu na reszcie terytorium" ${ }^{49}$.

W numerze 8 z $1947 \mathrm{r}$. pismo ustosunkowywało się do rocznicy dla przeciętnego odbiorcy nieco mniejszej wagi, lecz fundamentalnej z punktu widzenia emigracji, tj. 110-lecia wydania Manifestu Towarzystwa Demokratycznego Polskiego (4 XII 1836 r.), czyli 13 stron tekstu oraz komentarza „Centralizacji” (władz Towarzystwa). Autor artykułu, Tymon Terlecki ${ }^{50}$ zarysował proces przygotowywania dokumentu oraz uwypuklił rolę ponad „70 Sekcji” Towarzystwa - „niewielkich, ale żywotnych, współczynnych jak komórki żywego organizmu”, do których upodabniać powinna się także struktura PRW „NiD”. Objaśnił on też doniosłość manifestu i jego wpływ m.in. na powstanie z 1846 r., lutową odezwę Rządu Narodowego, „Skład zasad” dla Legionu Mickiewicza (do wieszcza odniósł się w 1949 r. kolejny znany profesor, tym razem slawista z Uniwersytetu Harvarda - Wiktor Weintraub ${ }^{51}$ ), rewolucję z 1863 r. czy dekret włościański z 22 stycznia następnego roku. Te influencje były obecne także w myśli oraz aktywności Bolesława Limanowskiego i jego imiennika - Wysłoucha, służących pozyskaniu chłopów i robotników dla sprawy polskiej. W XX w. walka z dwoma okupantami również wpisywała się w spuściznę Manifestu Towarzystwa Demokratycznego Polskiego, a dla wychodźstwa naczelną przesłanką było to, że dokument „po raz pierwszy tak dobitnie złączył w jedno - zagadnienie walki o niepodległość z zagadnieniem walki o formę życia zbiorowego, po raz pierwszy ujawnił sprzęgniecie tych spraw, ich wzajemną i całkowita współzależność”. Oczywiście nie brakowało opinii, że w połowie XX w. treści te dezaktualizowały się, niemniej jednak Terlecki podważał takie tezy, argumentując, iż po przeszło stuleciu wciąż „znajdowaliśmy się w tym samym miejscu, jakby w punkcie równoległym”, ponieważ nadal nie udało się scalić „sprawy narodowej ze sprawą społeczna, niepodległości z demokracja, i losu Polski z losem Europy, polskości z kultura zachodnią. Znowu co narodowe jest ludowe. Znowu co polskie jest europejskie, chrześcijańskie, co europejskie i chrześcijańskie jest polskie"52.

${ }^{49}$ Oferta bezwarunkowej kapitulacji, „Pół drogi do wolności” (jednodniówka PRW „NiD”), VI 1945 , s. 16.

${ }^{50}$ Więcej na temat dorobku T. Terleckiego zob. m.in.: Tymon Terlecki. Etos emigranta, red. J. Kryszak, M. Mroczkowska, Toruń 2004; Tymon Terlecki. Pamięć i sumienie emigracji, red. J. Jarzębski, A. Juszczyk, Przemyśl 2009.

${ }^{51}$ Biogram W. Weintrauba zob. A. Trudzik, W cieniu „zimnej wojny”... Weintraub podją się analizy wątku 50-lecia założenia „Trybuny Ludów”, a szczególnie - nader ożywionej w tym okresie - myśli społecznej Mickiewicza, z której wiele spostrzeżeń należało transponować do życia emigracji oraz przyszłej niepodległej i suwerennej Polski. Zob. W. Weintraub, W 150-lecie „Trybuny Ludów”, „Trybuna” 1949, nr 29, s. 6-7.

52 T. Terlecki, Po stu dziesięciu latach, „Trybuna” 1947, nr 8, s. 8-9. 
Ustalenie podobieństw i różnic między Pierwszą Wielką Emigracją a wychodźstwem wojennym i powojennym stanowiło jeden z priorytetów linii redakcyjnej czasopisma, która w tym kontekście w najogólniejszym zarysie sprowadzała się do tego, że w 1831 r. „rzeczywiście punkt ciężkości życia duchowego inicjatywy politycznej, społecznej i kulturalnej, ośrodek napięcia twórczego, ośrodek energii przesunął się poza granice Polski”, a "słowo płynące z emigracji, było przyjmowane jak objawienie z niebios". W latach czterdziestych ekspatrianci byli en bloc liczniejsi, lecz dysponowali mniejszym potencjałem państwowotwórczym, stąd ich naczelnym zadaniem miało być „podnoszenie głosu na forum świata [też w kontekście pielęgnacji tradycji - A.T.], na nich ciążył nakaz czynnego występowania zawsze i wszędzie, gdzie można i trzeba. Im wypadałoby przelewać krew, gdyby taki był nakaz historii. W kraju nie powinna się powtórzyć historia armii podziemnej i historia "czetników» Michajłowicza" 53 .

Powstanie listopadowe, jego upadek i w konsekwencji formowanie się Wielkiej Emigracji to kolejny „naturalny” wątek, który często gościł w periodyku. Marian Kamil Dziewanowski ${ }^{54}$, ceniony historyk, publicysta szkicował czytelnikom clou sporu natenczas toczonego, tj. przeciwstawnych wizji obozu demokratycznego z Joachimem Lelewelem na czele i arystokratycznego Hotelu Lambert kierowanego przez ks. Adama Czartoryskiego. Wywód autora sprowadzał się do zobiektywizowanej oceny, tzn. zaakcentowania, że środowisko Czartoryskiego „nie doceniało znaczenia narastających zagadnień społecznych i nie potrafiło sformułować w tej dziedzinie programu [...]; [zaś] obóz demokratyczny nie rozumiał znaczenia istotnych sił politycznych, grających w Europie współczesnej” ${ }^{55}$.

W jednym z pierwszych numerów „Trybuny” redivivus, jubileusze 50-lecia Bitwy Warszawskiej i jednocześnie 25-lecia konferencji jałtańskiej zainspirowały Rowmunda Piłsudskiego do oceny położenia Polski po II wojnie światowej, podkreślającego, że w $1945 \mathrm{r}$. sytuację na świecie podług polskiej racji stanu warunkowały dwa czynniki, tj. monopol USA na broń atomowa, który mógł dzięki temu zagwarantować pokój i bezpieczeństwo międzynarodowe, oraz jednocześnie prosowiecka polityka Franklina Delano Roosevelta, jego dezorientacja czy brak rozeznania w sprawach Europy Środkowo-Wschodniej. Ten drugi wątek stanowił continuum angielskiego modelu rozumienia tej części Europy, którego specyfiką było zajmowanie się wyłącznie Rosją bądź Niemcami i pomijanie mniejszych krajów ${ }^{56}$.

Strategię redakcyjną pisma w stosunku do ostatniego aspektu, tj. dziejotwórczych wydarzeń w trakcie i po II wojnie światowej, można usystematyzować

\footnotetext{
${ }^{53}$ Idem, My i Oni, „Trybuna” 1946, nr 7, s. 7-8.

${ }^{54}$ Biogram M.K. Dziewanowskiego zob. A. Trudzik, Polska i Europa Środkowo-Wschodnia..., s. 302 .

${ }_{55}$ M.K. Dziewanowski, Dwie emigracje, „Trybuna” 1947, nr 1, s. 7.

${ }^{56}$ R. Piłsudski, Dziś i wczoraj, „Trybuna” 1970, nr 6/62, s. 3-4.
} 
w trzech kategoriach: 1) wręcz euforycznie przyjmowane: wybór Karola Wojtyły na papieża i jego posługa ${ }^{57}$, festiwal „Solidarności” etc..$^{58 ;}$ 2) w pisujące się w „czarną kartę” historii: cofnięcie 6 VII 1945 r. uznania rządowi RP na uchodźstwie, odebrane jako „data historyczna w dziejach narodu polskiego, [która] otworzyła nową kartę Polski okupowanej i niewolnej dla Polaków na obczyźnie i otworzyła jednocześnie kartę emigracji politycznej dla Polaków na obczyźnie”. Do tej pory istniała emigracja „zetatyzowana i umundurowana ludzi sytych, wojsko i administracja państwowa przeniesione chwilowo na obcą ziemię, wierząca, iż niedługo wrócą do macierzy", a od chwili recognize nastała „emigracja z własnego wyboru” ${ }^{59}$; powołanie się w 1946 r. na raport w sprawie katyńskiej (tu: broszura wydana w Londynie) i skonfrontowanie go z ustaleniami sowieckimi, co prowadziło do przekonania, że „orzeczenie komisji sowieckiej" było wątpliwe, a konkretne przesłanki nakazywały „konieczność dalszych dochodzeń” ${ }^{\circ}$; casus Wąwolnicy - małego miasteczka w pobliżu Lublina, którego mieszkańców żydowskich „wymordowali Niemcy, ludność polską zdziesiątkowało NKWD i jego wykonawcy z Urzędu Bezpieczeństwa. W dniu 2 maja $1946 \mathrm{r}$. Wąwolnica została spalona przez agentów UB” ${ }^{61}$; wybory z 19 I 1947 r. ${ }^{62}$, które ,zamykały jeden i otwierały następny akt dramatu polskiego po drugiej wojnie światowej”, gdyż zostały one sfałszowane w trójnasób: „przed głosowaniem w drodze więzienia i gwałtów [...], w czasie głosowania - przez wezwanie do jawnego głosowania. I wreszcie po głosowaniu - przez zwyczajne sfałszowanie liczbowych wyników”63; uwięzienie prymasa Polski kard. Stefana Wyszyńskiego, w tym deklaracja CKW PRW „NiD” (umieszczona na s. 1) ${ }^{64}$; stan wojenny ${ }^{65}$; zabójstwo ks. Jerzego Popiełuszki itp. ${ }^{66}$; 3) interpretowane ambiwalentnie, np. Okragły Stól, o którym Grzegorz Górnicki (Grzegorz Drymer) ${ }^{67}$ pisał: „W chwili, gdy ten artykuł idzie do druku, z Okragłym Stołem nadal jeszcze na dwoje babka wróżyła, choć już coraz wyraźniej widać, że nie może przy nim dojść do prawdziwego porozumienia, a najwyżej «kontraktu», potwierdzającego tę swoistą wymianę barterową [...]"68.

57 G. Górnicki, Trzecia pielgrzymka Papieża do Polski, „Trybuna” 1987, nr 56/112, s. 3-4.

58 A. Pospieszalski, Sierpień 1980 w Polsce, „Trybuna” 1980, nr 36/92, s. 6-11; R. Piłsudski, O co chodzi?, „Trybuna” 1981, nr 37/93, s. 13-6; G. Górnicki, Wiosna „Solidarności”, „Trybuna” 1988, nr 58/144, s. 3-4.

${ }_{59}$ Rzad dusz emigracji, „Trybuna” 1946, nr 2, s. 1.

${ }^{60}$ Raport $w$ sprawie katyńskiej, „Trybuna” 1846, nr 6, s. 13-14.

${ }^{61}$ Wawolnica, „Trybuna” 1946, nr 3, s. 6.

${ }^{62}$ K. Zagórski, Wolne i sfałszowane, „Trybuna” 1946, nr 6, s. 2-3.

${ }^{63}$ Idem, Po 19 stycznia, „Trybuna” 1947, nr 8, s. 1-2.

${ }^{64}$ Tragiczny symbol, „Trybuna” 1953, nr 48, s. 1.

${ }^{65}$ J. Radomyski, Aspekt polityczny stanu wojennego, „Trybuna” 1982, nr 40/96, s. 3-6.

${ }^{66}$ Idem, Pośmiertne zwycięstwo ks. Popietuszki, „Trybuna” 1984, nr 48/104, s. 1, 4.

${ }^{67}$ Biogram G. Drymera zob. A. Trudzik, Polska i Europa Środkowo-Wschodnia..., s. 301.

${ }^{68}$ G. Górnicki, Okragty Stót: „Czy warto byto z losem się droczyć...”, „Trybuna” 1989, nr $60 / 116$, s. $8-10$. 
Wtórował mu Krzysztof Turowski69, przyznając, że jego rezultaty „nie były na miarę potrzeb [...]. Wydaje się, że na więcej nie tylko władza nie chciała się zgodzić, ale i opozycji dyskutującej przy stole nie było stać. Niestety"70. Niezależnie od publicystyki w periodyku „NiD” oficjalnie podjął uchwałę popierajaca Okragły Stół, zaapelował do poparcia Komitetu Obywatelskiego „Solidarność" w wyborach parlamentarnych i pogratulował Adamowi Michnikowi założenia „Gazety Wyborczej” (przekazując na jego ręce £100) ${ }^{71}$.

Warto jeszcze zwrócić uwagę na to, że numer 22 z 1976 r. Rowmund Piłsudski otwierał tekstem o geście bezspornie ekstraordynaryjnym, tzn. wystosowaniu przez krajowych intelektualistów Listu 59, który redakcja przytoczyła expressis verbis, zamieszczając również oświadczenie Wydziału Wykonawczego Federacji Ruchów Demokratycznych (FRD) w tej sprawie. W następnym wydaniu wydrukowano list prof. Edwarda Lipińskiego do Edwarda Gierka, będacy sui generis echem dokumentu, wraz z komentarzami w prasie emigracyjnej („Robotnik”) oraz porównano List 59 z czechosłowacka Karta $77^{72}$. Osobnym wątkiem, jaki wypełniał na początku lat osiemdziesiątych łamy „Trybuny”, było „ratowanie POSK-u” jako symbolu Drugiej Wielkiej Emigracji nad Tamiza. Redakcja postulowała w tej materii przyjęcie niezłomnej postawy: „należy zrobić wszystko, aby go uratować”, co najmniej z dwóch powodów, a mianowicie „w miarę jak zbliżał się koniec biologiczny naszej emigracji wojennej coraz ważniejszą stawała się sprawa co po sobie pozostawimy. Nie było nam dane wywalczyć wolności krajowi, stworzyliśmy jednak bazę dla kontynuowania walki i tę wolność przez naszych następców” (tu: Polski Ośrodek Społeczno-Kulturalny [POSK]). Druga okoliczność nie mniej przemawiała do wyobraźni, albowiem suponowano, iż jeśli gmach ośrodka poddano by pod licytację, to pierwszym aplikujaccym o jego nabycie byłaby prawdopodobnie „ambasada reżymowa”, która „osiagnęłaby podwójny cel”, tzn. zdobyłaby przyczółek do „dywersyjnej akcji” wśród uchodźstwa, a równocześnie „kompromitowałaby czynniki kierownicze emigracji politycznej w oczach polskich i brytyjskich"73.

Na zakończenie wypada wspomnieć, że w organie prasowym Ruchu sukcesywnie kierowano uwagę w stronę Powstania Warszawskiego, w którym nota bene walczyło wielu nidowców, stąd nie mogło dziwić, że już w jego rocznicę uwypuklano fakt, iż na jego temat „spory i wątpliwości nie zdążyły jeszcze przycichnąć; jeżeli będzie z nich wyciagnięta właściwa nauka na przyszłość,

${ }^{69}$ Biogram K. Turowskiego zob. A. Trudzik, W cieniu „zimnej wojny”...

${ }^{70}$ K. Turowski, Rozważania o opozycji, „Trybuna” 1989, nr 61/117, s. 12.

71 Uchwaty Rady naczelnej PRW „NiD”, „Trybuna” 1989, nr 61/117, s. 4-6.

72 R. Piłsudski, Historyczny dokument, „Trybuna” 1976, nr 22/78, s. 1-4; List 59, w: Dokumenty, „Trybuna” 1976, nr 22/78, s. 6; Oświadczenie Wydziału Wykonawczego FRD, w: Wydarzenia $i$ komentarze, „Trybuna” 1976, nr 22/78, s. 26; Echo listu 59, w: Dokumenty, „Trybuna” 1976, nr 23/79, s. 29-31; Karta 77 i List 59-ciu, „Trybuna” 1977, nr 25/81, s. 30-31.

${ }^{73}$ Sprawa POSKu, „Trybuna” 1980, nr 34/90, s. 29. 
potrzebne są rozważania krytyczne i pełna świadomość genezy, przebiegu i skutków” tego zrywu. Z upływem czasu dla „Trybuny” i członków ugrupowania oczywiste stawało się, że w „konkretnych warunkach, w jakich wówczas znalazł się naród polski, była to jedyna, choć tak tragicznie kosztowna możliwość wyrażenia woli niepodległości”. Obok celu militarnego i politycznego podnoszono argument wyższego rzędu, tzn. że powstanie miało być zarzewiem i „początkiem nowej Polski” ${ }^{4}$. Temat - z okazji 5-lecia - rozwiną jeden z uczestników, Andrzej Pomian, który nie godził się z tym, że niejednokrotnie $\mathrm{w}$ wypowiedziach, poglądach czy nawet analizach powstanie interpretowano przez pryzmat „wydarzenia oderwanego, które zadecydowano 31 lipca $1944 \mathrm{r}$. i rozpoczęto dokładnie 1 sierpnia, trwającego do 2 października", podczas gdy właściwa jego ocena wymagała podejścia holistycznego, kompleksowego, kontekstowego ${ }^{75}$. Interesująco i oryginalnie uczczono 10-lecie, albowiem wydrukowano wiersz Dzieto dla rqk Krzysztofa Kamila Baczyńskiego ${ }^{76}$.

\section{Streszczenie}

Z trzech podstawowych form upamiętniania świąt (nade wszystko 3 Maja, 15 sierpnia, 11 listopada) i innych jubileuszów historycznych przez PRW „NiD” z pewnością w dwóch z nich aktywność Ruchu była szczególnie zintensyfikowana (organizacja i uczestnictwo w różnego rodzaju inicjatywach jubileuszowych - jako Ruch oraz indywidualne, a także publikacje i polemika na łamach „Trybuny”), natomiast w mniejszym stopniu aktywność ta została ukierunkowana na działalność formalnoprawna, tj. wydawanie uchwał, deklaracji, apeli etc. Uwzględniając zebrania, konferencje, wieczory dyskusyjne, odczyty, prelekcje itd., z pewnością szczególną estymą darzono rocznicę uchwalenia Konstytucji 3 maja, ale też pielęgnowano obchodzenie świąt religijnych. Do lat siedemdziesiątych rzadko pojawiały się dokumenty, których treść bezpośrednio wiązała się z jubileuszami, zaś od tego czasu było ich wydawanych więcej, aczkolwiek wówczas ugrupowanie w coraz większym zakresie skupiało się na bieżących zagadnieniach, stąd odwołań do przeszłości było relatywnie niewiele. Wreszcie publicystyka i polemika w „Trybunie" okazała się najbardziej złożona, gdyż posiłkowano się w niej zarówno pozytywnymi, jak i negatywnymi przykładami z historii Polski, oprócz „kalendarza” obowiązujących już jubileuszów, prognozowano, jakie wydarzenia będą pełniły rolę symboli w przyszłości, ale też często przy okazji posługiwania się ważnymi rocznicami historycznymi komentowano współczesność.

\section{Activity of the Polish Freedom Movement "Independence and Democracy" and Political Commentary Journalism in the Trybuna Monthly in the Context of Commemorating Historical Anniversaries and Cherishing a Sense of Polishness in Exile}

Of the three basic forms of commemorating national days (above all 3 May, 15 August, 11 November) and other historical anniversaries by the Polish Freedom Movement "Independence and Democracy" (PRW NiD), certainly in two of them the activity of the Movement was

\footnotetext{
${ }^{74}$ Wielka rocznica, „Trybuna” 1947, nr 11, s. 3.

75 A. Pomian, Pięć lat, „Trybuna” 1949, nr 30, s. 2.

76 10-ta rocznica, „Trybuna” 1954, nr 52, s. 3.
} 
particularly intense (organisation and participation in various jubilees both of the Movement as the whole and of individual members, and publications and polemics in the Trybuna monthly). To a lesser extent this activity was focused on issuing resolutions, declarations, appeals, etc. From among meetings, conferences, discussion evenings, lectures, lectures, etc., it was the Constitution Day celebrating the anniversary of the adoption of the 3 May 1791 Constitution that was held in special respect, but also the celebration of certain religious holidays. Until the 1970 s, documents directly related to the anniversaries of historical events were rarely published, there have been more of them later on, although at that time the group increasingly focused on current issues, hence the references to the past were relatively few. Finally, journalism and polemics in the Trybuna was the most complex because it used both positive and negative examples from the history of Poland; apart from the calendar of the already obligatory anniversaries, the authors predicted what events would play the role of symbols in the future, but also commented on the present day when important historical anniversaries were used.

\section{Bibliografia}

Giedroyc J., Autobiografia na cztery ręce, Warszawa 2006.

Juchnowski R., Rowmund Pitsudski 1903-1988. Koncepcje polityczne i społeczne, Wrocław 2009. Lerski J., Emisariusz „Jur”, Warszawa 1988.

Łukasiewicz S., Partia w warunkach emigracji. Dylematy Polskiego Ruchu Wolnościowego „Niepodległość i Demokracja” 1945-1994, Warszawa-Lublin 2014.

Łukasiewicz S., Śp. Piotr Wandycz z perspektywy Lublina - pożegnanie, „Yearbook of the Institute of East-Central Europe" 2017, t. XV, nr 1.

Piątkowska-Stepaniak W., „Nowy Dziennik” w Nowym Świecie. Pismo i jego rola ideowo-polityczna, Opole 2000.

Siwik A., Polska Partia Socjalistyczna na emigracji w latach 1945-1956, Kraków 1998.

Siwik A., Polskie uchodźstwo polityczne. Socjaliści na emigracji w latach 1956-1990, Kraków 2002.

Trudzik A., Myśl społeczno-polityczna Polskiego Ruchu Wolnościowego (PRW „NiD”) w latach 1945-1955, Warszawa 2010.

Trudzik A., Paryska „Kultura”- londyńska „Trybuna”(1945-55). Idee i programy, w: Paryż Londyn - Monachium - Nowy Jork. Powrześniowa emigracja niepodległościowa na mapie kultury nie tylko polskiej, red. V. Wejs-Milewska, E. Rogalewska, Białystok 2009.

Trudzik A., Pierwsza dekada działalności Polskiego Ruchu Wolnościowego „Niepodległość $i$ Demokracja” (PRW „NiD”). Wspótczesna perspektywa badawcza, „Studia Medioznawcze" 2009, nr 3.

Trudzik A., Polska i Europa Środkowo-Wschodnia w perspektywie londyńskiej „Trybuny” po 1956 r., Szczecin 2016.

Trudzik A., Polski Ruch Wolnościowy „Niepodlegtość i Demokracja” i jego organ prasowy „Trybuna”. Dzieje Ruchu, periodyku i innych czasopism wydawanych przez PRW „NiD”, Warszawa 2009.

Trudzik A., Portret zbiorowy członków Polskiego Ruchu Wolnościowego „Niepodległość i Demokracja” oraz publicystów „Trybuny”, w: Media lokalne i dziennikarstwo. Aspekty wspótczesne i historyczne, red. nauk. K. Pokorna-Ignatowicz, S. Michalczyk, Kraków 2010.

Trudzik A., PRW „NiD” $i$ londyńska „Trybuna” wobec tradycji romantycznej i pozytywistycznej, w: Piekło i niebo Polaków. Powstania narodowe, bunty i rewolucje. Inspiracje - kontynuacje - spory - pamięć, red. T. Sikorski, M. Śliwa, A. Wątor, t. I, Kraków 2014.

Tymon Terlecki. Etos emigranta, red. J. Kryszak, M. Mroczkowska, Torun 2004.

Tymon Terlecki. Pamięć i sumienie emigracji, red. J. Jarzębski, A. Juszczyk, Przemyśl 2009. 
Biog r a m: Artur Mariusz Trudzik - dr; adiunkt w Zakładzie Mediów i Komunikowania Uniwersytetu Szczecińskiego. W dorobku 5 książek monograficznych i 3 jako współredaktor; autor 50 artykułów naukowych. Główne zainteresowania badawcze: dziennikarstwo muzyczne (obecnie) oraz Druga Wielka Emigracja, w tym myśl społeczno-polityczna i dzieje mediów wychodźczych; historia polskich mediów w XX i XXI w. Najważniejsze publikacje: Polski Ruch Wolnościowy „Niepodległość i Demokracja” $i$ jego organ prasowy - „Trybuna”. Dzieje ruchu, periodyku i innych czasopism wydawanych przez PRW „NiD” (2009); Myśl spoteczno-polityczna Polskiego Ruchu Wolnościowego (PRW „NiD”) w latach 1945-1955 (2010); Polska prasa muzyczna $w$ dobie transformacji ustrojowej. „Tylko Rock” 1991-2002 (2017); Prasa rockowa w PRL-u. „Magazyn Muzyczny” 1980-1991 (w druku). E-mail: arttru@interia.pl. 